\title{
STUDIES ON THE CONDITIONS OF GLUCOSE EXCRETION IN MAN
}

\author{
BY KURT STEINITZ
}

(From the Department of Medicine of Istanbul University, Guraba Hospital, Istanbul, Turkey)

(Received for publication September 29, 1939)

The application of the filtration reabsorption theory to the explanation of glucose excretion has been of great importance for our knowledge of the factors involved in this process. In normal and pathologic conditions the quantity of glucose excreted is dependent only on three factors: the level of the capillary blood sugar, the filtration rate and the glucose threshold.

We may assume that the glucose level of the glomerular filtrate is the same as that of the arterial plasma. The quantity of the filtered glucose is determined by two factors: the level of the arterial blood sugar and the quantity of the filtration rate. Under normal circumstances, the glucose is almost completely reabsorbed by the tubules. In a unit of time only a constant, maximal quantity of glucose can be transported by the tubular cells, as Shannon and Fisher (14) demonstrated for the normal dog, Govaerts and Muller (3) for the diabetic dog. Under normal condi-

or

(2) glucose threshold $=$ blood sugar $-\frac{\text { urine sugar, mgm. per cent } X \text { plasma creatinine, mgm. per cent }}{\text { creatinine in urine, mgm. per cent }}$

So far, the threshold in man has been determined by oral administration of glucose. The blood sugar is tested at close intervals and the appearance of sugar is noted in the urine. The disadvantage of this procedure lies in the fact that the rise of the blood sugar curve may be very rapid, and the peak very brief. Most of the authors have observed a high ascending and a low descending threshold. In this article we will not discuss whether this difference really exists or whether it is due only to the experimental conditions (cf. Govaerts and Muller (2), Peters and Van Slyke (9), Falta (1)). Moreover, it is only possible to provoke glycosuria by oral administration in a certain percentage of subjects (16).

To avoid these difficulties, we tried to fix the tions this reabsorbing capacity of the tubules is not fully utilized and the excretion of glucose is almost zero. When the blood sugar, and in consequence the filtered quantity of glucose, has been increased or has just risen to the full utilization of the reabsorbing capacity, the blood sugar has reached the threshold. The quantity of the maximal reabsorbed glucose therefore depends on two factors: the level of the threshold and the quantity of the filtration rate.

If the blood sugar rises above this threshold, the maximal capacity of reabsorption is surpassed and the glucose appears in the urine. Glucose filtered - glucose reabsorbed = glucose excreted. This excess glucose, which has not undergone reabsorption, is now concentrated at the same rate as other substances which are neither reabsorbed nor secreted from the tubules, such as inulin or endogenous creatinine. One can express this relationship by the following equation (2):

glucose excreted, mgm. per minute

(blood sugar - threshold), mgm. per cent threshold by another method, that is, as already stated, by the determination of that part of the blood sugar which is treated like a substance that has neither been reabsorbed nor secreted. To render this possible, the existence of a frank glycosuria is indispensable. When glycosuria was absent, it was produced by intravenous infusion of glucose in order to obtain a constant plasma level of glucose. For the following reasons it is impossible to compare the results of this method with the aforesaid oral administration method without certain considerations.

From their experiments with dogs Shannon and Fisher (14) have reached an equation "according to which it is to be expected that small 
concentrations of glucose will appear in the urine at normal plasma glucose levels, that there will be a little increase in the rate of excretion as the plasma level rises until the maximal rate of reabsorption is approached, and that the maximal rate of reabsorption will thereafter be rapidly attained." Govaerts and Muller $(2,3)$ obtained exactly the same results. They called that level of blood sugar at which the first traces of glucose appear "seuil d'apparition," according to the definition of C. Bernard, whereas they called the higher level of blood sugar, above which there exists a direct proportionality between "supralimitary" blood sugar and the amount of glucose excreted, the "seuil maximum."

With our method we have not determined the threshold of appearance, but the maximum threshold. It is rather probable, however, that these two thresholds are not very different from each other. Experiments in dogs show "that a small but significant amount of glucose first appears in the urine when the plasma concentration is 10 to $20 \mathrm{mgm}$. per cent below the level at which the maximal rate of reabsorption is reached." One of our experiments seems to demonstrate that this difference is not greater in man, and that between the level of the threshold of appearance and that of the maximum threshold only very small amounts of glucose are excreted. These amounts are not important for the excretion rate of glucose in diabetic patients.

\section{METHODS}

In patients with a spontaneous glycosuria technic A was employed. Urine and blood were collected as described by Möller, McIntosh and Van Slyke (6) for the urea clearance. At the beginning, in the middle, and at the end of the test, the capillary blood sugar was determined by the method of Hagedorn and Jensen. The results of these determinations must not differ very much from each other. The sugar in urine was determined by polariscopic examination after previous precipitation with lead acetate. The creatinine in blood plasma and urine was determined by the method of Popper and Mandel (10). Patients with acetonuria were excluded from the test, as the values of creatinine in plasma and urine increase considerably in the presence of acetone. An attempt was made to remove the acetoacetic acid and the acetone by boiling the picric acid filtrate, but the results were not satisfactory since, in spite of the removal of acetone, the chromogenic substance increased slightly, even during a short boiling period.
Glucose was introduced in patients without glycosuria by an intravenous infusion, and the period was started if a frank glycosuria was present (technic B). In some cases the inulin clearance was determined simultaneously (technic C). The collection of urine and blood, the technic of infusion and the analytical methods were the same as described in the previous paper (15). The amount of glucose necessary to produce a glycosuria was approximately the same as described by Sansum and Woodyatt (13). Glucose was given as a 20 per cent solution at a rate of $5 \mathrm{cc}$. per minute. After 25 to 30 minutes glucose appeared in the urine, and the first period began.

Increased plasma glucose gives a faint color reaction with the modified Selivanoff's reagent (11). According to the increase of blood glucose during the experiment, glucose was added to the fasting blood filtrate in order to compensate for this color. The value of extinction of this blank analysis was subtracted from the other values. Glucose in blood and urine was determined as already described. Only in experiments with inulin was the sugar in urine determined by the reduction of titrated Benedict's reagent.

\section{Normal subjects}

Table I shows the results in 4 normal subjects. The maximum threshold in these subjects lies between 200 and $280 \mathrm{mgm}$. per cent. In Case 4 we tried to determine the difference between the threshold of appearance and the maximum threshold. After a priming infusion of 10 per cent glucose with 5 per cent inulin, a second infusion of 10 per cent glucose with 1 per cent inulin was given at a rate of $5 \mathrm{cc}$. per minute until the blood sugar remained constant between 173 and 179 mgm. per cent. At the same time the filtration rate was determined. Then a third infusion of 20 per cent glucose with 1 per cent inulin was given at the same rate. The first glucose could be found in the urine at a blood sugar level between 194 and $209 \mathrm{mgm}$. per cent. At a blood sugar level of $220 \mathrm{mgm}$. per cent the same value for the threshold was found. Unfortunately, the patient was not able to bear the infusion any longer but it seems probable that the threshold would not have increased much at higher blood sugar levels.

\section{Diabetes renalis}

We were recently able to examine 4 cases of true renal glycosuria. As these cases are relatively rare, a short report will be of interest. The results of these cases are given in Table II. 
TABLE I

Normal subjects

\begin{tabular}{|c|c|c|c|c|c|c|c|c|c|}
\hline Technic & Subject & Age & $\begin{array}{l}\text { Urine } \\
\text { flow }\end{array}$ & $\begin{array}{l}\text { Creatinine } \\
\mathrm{U} / \mathrm{P} \text { ratio }\end{array}$ & $\begin{array}{l}\text { Sugar } \\
\text { in urine }\end{array}$ & $\begin{array}{c}\text { Supra- } \\
\text { limitary } \\
\text { blood } \\
\text { glucose }\end{array}$ & $\begin{array}{l}\text { Blood } \\
\text { sugar }\end{array}$ & $\begin{array}{c}\text { Thresh- } \\
\text { old }\end{array}$ & $\begin{array}{l}\text { Reabsorbed } \\
\text { glucosed }\end{array}$ \\
\hline $\begin{array}{l}\mathrm{C} \\
\mathrm{C}\end{array}$ & $\begin{array}{l}\text { Ismail } \\
\text { Shemsi } \\
\text { Hikmet }\end{array}$ & 18 & $\begin{array}{c}\text { cc. per minute } \\
11.9 \\
16.4 \\
18.5 \\
14.0 \\
16.4 \\
12.4 \\
12.0 \\
3.85 \\
6.28 \\
16.8 \\
12.1\end{array}$ & $\begin{array}{l}10 \\
8.5 \\
7.75 \\
8.95 \\
10 \\
10 \\
10 \\
25.5 \\
17.5 \\
7.65 \\
7.65\end{array}$ & $\begin{array}{c}\text { mgm. per cent } \\
1100 \\
800 \\
700 \\
300 \\
700 \\
800 \\
900 \\
1280 \\
1310 \\
45 \\
210\end{array}$ & $\begin{array}{c}\text { mgm. per cent } \\
110 \\
94 \\
90.5 \\
33.5 \\
70 \\
80 \\
90 \\
51.5 \\
76 \\
5.9 \\
27.4\end{array}$ & $\begin{array}{c}\text { mgm. per cent } \\
389 \\
376 \\
334 \\
305 \\
279 \\
299 \\
309 \\
298 \\
323 \\
201 \\
220\end{array}$ & $\begin{array}{c}\text { mgm. per cent } \\
279 \\
282 \\
244 \\
272 \\
209 \\
219 \\
219 \\
247 \\
247 \\
195 \\
193\end{array}$ & \begin{tabular}{|c} 
msm. per minute \\
332 \\
392 \\
348 \\
339 \\
343 \\
271 \\
264 \\
236 \\
268 \\
251 \\
180
\end{tabular} \\
\hline
\end{tabular}

Case 1. Münevver is a female of 27 years. Towards the end of the first pregnancy sugar was found in the urine during a casual examination. At a second examination some weeks after the delivery sugar was found again and assumed to be lactose. Three months after the delivery the patient was admitted to the hospital. The daily sugar output fluctuated between 35 and 50 grams, the fasting blood sugar level being $88 \mathrm{mgm}$. per cent. The sugar was identified as glucose as follows:

1. Reduction and polariscopic examination gave the same quantity of glucose.

2. The fermentation with yeast began quickly. After complete fermentation the capacity of reduction disappeared.

3. The tests of Rubner, Wöhlk and Malfatti for lactose were negative (8).

4. The characteristic formation of mucic acid was negative.

5. The phenylosazone was formed quickly and copiously during heating. Lactosazone, however, is soluble in the heat.

The results of tests 2 to 5 proved the absence of lactose. The oral administration of $\mathbf{5 0}$ grams of glucose was followed by a quite normal blood sugar curve. The sugar in urine rose to 6.3 per cent. After the injection of 12 units of insulin the blood sugar decreased during 3 hours from 109 to $69 \mathrm{mgm}$. per cent. At this level the glucose excretion ceased.

During the time of hospitalization the daily excretion of sugar was 30 to 50 grams at an intake of 250 grams of carbohydrates. The fasting blood sugar level was always normal. During the observation time, from April to December 1938, no change occurred.

Case 2. Shevket is a male of 30 years. Sugar was found in the urine during a casual examination. The glucose tolerance test had been performed in another hospital and had been followed by a normal blood sugar

TABLE II

Diabetes remalis

\begin{tabular}{|c|c|c|c|c|c|c|c|c|c|c|}
\hline Date & Technic & Subject & Age & $\begin{array}{l}\text { Urine } \\
\text { flow }\end{array}$ & $\begin{array}{l}\text { Creatinine } \\
\text { U/P ratio }\end{array}$ & $\begin{array}{l}\text { Sugar } \\
\text { in urine }\end{array}$ & $\begin{array}{c}\text { Supra- } \\
\text { limitary } \\
\text { blood } \\
\text { glucose }\end{array}$ & $\begin{array}{l}\text { Blood } \\
\text { sugar }\end{array}$ & $\begin{array}{l}\text { Thresh- } \\
\text { old }\end{array}$ & $\begin{array}{l}\text { Reabsorbed } \\
\text { glucose }\end{array}$ \\
\hline $\begin{array}{l}\text { April 21, } 1938 \\
\text { Feb. 17, } 1939 \\
\text { April 20, } 1939 \\
\text { June } 2,1939 \\
\text { June } 6,1939 \\
\text { June } 13,1939\end{array}$ & $\begin{array}{l}\mathbf{A} \\
\mathbf{A} \\
\mathbf{A} \\
\mathbf{A} \\
\mathbf{A} \\
\mathbf{A}\end{array}$ & $\begin{array}{l}\text { Münevver } \\
\text { Shevket } \\
\text { Agop } \\
\text { Ayshe } \\
\text { Ayshe } \\
\text { Ayshe }\end{array}$ & $\begin{array}{l}27 \\
30 \\
18 \\
37 \\
37 \\
37\end{array}$ & $\begin{array}{l}\text { cc. per } \\
\text { minute } \\
0.57 \\
0.51 \\
0.53 \\
0.45 \\
0.56 \\
0.397 \\
1.02 \\
0.74 \\
0.50 \\
0.59 \\
0.84 \\
1.03 \\
0.54 \\
0.88 \\
0.74\end{array}$ & $\begin{array}{l}207 \\
240 \\
286 \\
131 \\
234 \\
307 \\
137 \\
137 \\
132 \\
125 \\
101 \\
104 \\
128 \\
157 \\
157\end{array}$ & $\begin{array}{c}\text { mgm. per } \\
\text { cerit } \\
3850 \\
600 \\
1000 \\
140 \\
2500 \\
3400 \\
2000 \\
2500 \\
3400 \\
5400 \\
4700 \\
3000 \\
2400 \\
3000 \\
3500\end{array}$ & $\begin{array}{c}\text { mgm. per } \\
\text { cent } \\
18.6 \\
2.5 \\
3.5 \\
1.0 \\
10.7 \\
11.0 \\
14.6 \\
18.3 \\
25.7 \\
43.2 \\
46.5 \\
28.9 \\
18.7 \\
19.1 \\
19.1\end{array}$ & $\begin{array}{c}\text { mgm. per } \\
\text { cent } \\
88 \\
85 \\
98 \\
53 \\
91 \\
91 \\
88 \\
97 \\
107 \\
116 \\
109 \\
89 \\
86 \\
87 \\
87\end{array}$ & $\begin{array}{c}\text { mgm. per } \\
\text { cent } \\
69 \\
82 \\
94 \\
52 \\
80 \\
80 \\
73 \\
79 \\
81 \\
73 \\
63 \\
60 \\
67 \\
68 \\
68\end{array}$ & $\begin{array}{c}\text { mgm. per } \\
\text { minute } \\
82 \\
102 \\
143 \\
31 \\
105 \\
98 \\
103.5 \\
80 \\
54 \\
53 \\
53 \\
65 \\
46.5 \\
94 \\
79.5\end{array}$ \\
\hline
\end{tabular}


curve, with abundant sugar excretion in the urine. We had no occasion to study this case more completely.

Case 3. Agop is a boy of 17 years. The first examination took place on April 20, 1935. Some time before this date a glycosuria was found incidentally and the existence of a diabetes mellitus was assumed. The result of the glucose tolerance test at that time was normal, but the sugar excretion rose to 3 per cent. The tolerance test with 100 grams of white bread gave a similar result. Since then we saw the patient only at irregular intervals. The daily glucose output was always about 20 grams, the fasting blood sugar being normal. The determination of the threshold was made on April 20, 1939.

Case 4. Ayshe is a female of 37 years. Four months ago she had a delivery with forceps. Twenty-five days later a manifestation of syphilis was found in her mouth. The Wassermann test was positive. Treatment with neosalvarsan and bismuth was begun. During the treatment sugar was found in her urine for the first time. The doctor assumed a diabetes mellitus, but dietetic treatment was without success. She was hospitalized on May 31, 1939. The sugar in the urine was identified as glucose as described in Case 1. As the resident physician had at first believed the case to be a diabetes mellitus, a fasting day and afterwards a vegetable day were ordered. On the following day, June 2, the threshold of glucose was found at $52 \mathrm{mgm}$. per cent at a glycosuria of 0.14 per cent. Now the patient was given usual food which contained more than 250 grams of carbohydrates. The daily sugar excretion rose to 25 to $\mathbf{4 0}$ grams. The glucose tolerance test on June 5 "showed only a slight hyperglycemic response. The blood sugar rose from $77 \mathrm{mgm}$. per cent to $119 \mathrm{mgm}$. per cent, at a sugar excretion up to 6.8 per cent. The determination of the threshold was repeated on June 6 , and $80 \mathrm{mgm}$. per cent were found at a sugar excretion of 3.5 per cent. On June 8, 10 units of insulin were injected into the fasting patient. The blood sugar fell from $71 \mathrm{mgm}$. per cent to $33 \mathrm{mgm}$. per cent. Even at this low blood sugar level in urine, 0.2 per cent sugar was excreted. After a week the determination of the threshold was made once more and repeated each hour from morning to afternoon. The patient is still in the hospital. Every day she excretes 20 to 35 grams of sugar at a normal blood sugar level.

In all the cases there exists an obvious inability of the tubules to reabsorb glucose in sufficient quantities. No conclusions concerning a uniform etiology can be drawn from these observations. The anamnesis gave no evidence of hereditary factors. The rôle of pregnancy in Cases 1 and 4 is not clear, as the non-existence of glycosuria before pregnancy has not been proved.

Monasterio (7) was the first to detect an anatomical anomaly of the renal tubules in one case of renal glycosuria. An enormous dilatation of the lumen with flattening of the tubular epithelium was found. In our cases we had no occasion to suggest an operation to the otherwise normal patient. If further evidence from more cases is added, it will perhaps be possible to characterize some of the cases of renal glycosuria as an anatomical anomaly of the kidney.

We will not discuss here the mechanism of the failure of the tubular cells to transfer glucose. The results of Rühl and Thaddea (12), who treated 2 cases with adrenal cortex hormone, are not yet very conclusive. Hoff (4) demonstrated the influence of lactoflavine and corticosterone on the phlorizin glycosuria.

The values of the threshold, determined during insulin hypoglycemia as well as by the "supralimitary" blood glucose, agree very well in Case 1. In this case a difference between the threshold of appearance and the maximum threshold does not seem to exist. In Case 4, however, this difference seems to be obvious. After 2 fasting days the threshold is $52 \mathrm{mgm}$. per cent at a just perceptible glycosuria. During insulin hypoglycemia the threshold appears to lie much lower still. A complete renal diabetes seems to exist because the greatest part of the blood sugar value of 33 mgm. per cent, determined by the method of Hagedorn-Jensen, is formed by non-glucose-reducing substances. If glucose is filtered more copiously, however, the threshold rises to 70 to 80 mgm. per cent.

\section{Diabetes mellitus}

The determination of the threshold in patients with diabetes mellitus gave the same values as in normal subjects (Table III). The tests of some patients of advanced age and of patients whose diabetes had existed for a very long time, however, sometimes gave much higher values. In clinical practice this fact has been known for a long time but until now an explanation for the increased capacity to reabsorb glucose has not been found.

\section{Reduced kidney function}

One patient with amyloidosis in the terminal stage and with extremely low kidney function, and 1 patient with malignant hypertension were examined with technic B (Table IV). The de- 
TABLE III

Diabetes mellitus

\begin{tabular}{|c|c|c|c|c|c|c|c|c|c|}
\hline Date & Technic & Subject, age and sex & $\begin{array}{l}\text { Urine } \\
\text { flow }\end{array}$ & $\begin{array}{l}\text { Creatinine } \\
\text { U/P ratio }\end{array}$ & $\begin{array}{c}\text { Sugar } \\
\text { in urine }\end{array}$ & $\begin{array}{c}\text { Supra- } \\
\text { limitary } \\
\text { blood } \\
\text { glucose }\end{array}$ & $\begin{array}{l}\text { Blood } \\
\text { sugar }\end{array}$ & $\begin{array}{c}\text { Thresh- } \\
\text { old }\end{array}$ & $\begin{array}{l}\text { Reabsorbed } \\
\text { glucose }\end{array}$ \\
\hline $\begin{array}{l}\text { May 2, } 1938 \\
\text { June 28, } 1938 \\
\text { Mar. 13, } 1939 \\
\text { April 25, } 1939 \\
\text { May 15, } 1939 \\
\text { May 22, } 1939\end{array}$ & $\begin{array}{l}\mathbf{A} \\
\mathbf{A} \\
\mathbf{A} \\
\mathbf{A} \\
\mathbf{A} \\
\mathbf{A}\end{array}$ & 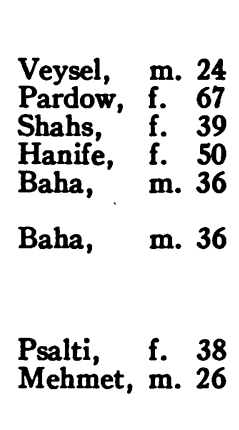 & $\begin{array}{l}c c . \text { per } \\
\text { minute } \\
1.09 \\
0.58 \\
0.62 \\
1.10 \\
3.75 \\
3.87 \\
1.13 \\
1.41 \\
1.87 \\
1.85 \\
0.48 \\
0.55 \\
0.55\end{array}$ & $\begin{array}{c}51.2 \\
148 \\
174 \\
118 \\
44.4 \\
43.2 \\
98 \\
74.5 \\
57.7 \\
57.7 \\
364 \\
225 \\
225\end{array}$ & $\begin{array}{c}\underset{\text { mgm. per }}{\text { cent }} \\
1400 \\
1550 \\
8500 \\
600 \\
5000 \\
5000 \\
2940 \\
3120 \\
3850 \\
4270 \\
1700 \\
4670 \\
4670\end{array}$ & $\begin{array}{c}\text { mgm. per } \\
\text { cent } \\
27.3 \\
10.5 \\
49 \\
5 \\
113.5 \\
111 \\
30 \\
42 \\
67 \\
74.3 \\
4.7 \\
20.8 \\
20.8\end{array}$ & $\begin{array}{c}\underset{\text { mgm. per }}{\text { cent }} \\
237 \\
205 \\
304 \\
272 \\
399 \\
403 \\
295 \\
303 \\
312 \\
324 \\
260 \\
280 \\
259\end{array}$ & $\begin{array}{c}\underset{\text { mgm. per }}{\text { cent }} \\
210 \\
195 \\
255 \\
267 \\
286 \\
292 \\
265 \\
261 \\
245 \\
250 \\
255 \\
259 \\
238\end{array}$ & 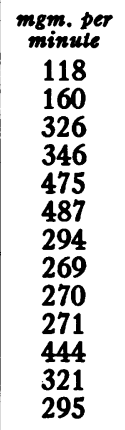 \\
\hline \multicolumn{10}{|c|}{ Diabetes mellitus with high glucose threshold } \\
\hline $\begin{array}{l}\text { June } 28,1939 \\
\text { July } 7,1939 \\
\\
\text { July } 12,1939\end{array}$ & $\stackrel{\mathrm{B}}{\mathrm{C}}$ & $\begin{array}{ll}\text { Ziya, } & \text { m. } 62 \\
\text { Ahmet, } & \text { m. } 65 \\
\text { Özat, } & \text { m. } 63 \\
\text { Mahir, } & \text { m. } 60\end{array}$ & $\begin{array}{l}4.18 \\
4.50 \\
5.42 \\
3.30 \\
5.73 \\
5.39 \\
3.29 \\
3.323 \\
4.28 \\
5.00 \\
6.33 \\
0.98 \\
1.51\end{array}$ & $\begin{array}{l}22.5 \\
19.2 \\
15.4 \\
31.6 \\
30.5 \\
26 \\
32.4 \\
18.5 \\
18.2 \\
17.1 \\
13.5 \\
64.7 \\
60.2\end{array}$ & $\begin{array}{r}3060 \\
3900 \\
3880 \\
3870 \\
3560 \\
3620 \\
2100 \\
1190 \\
2030 \\
2260 \\
2050 \\
900 \\
1000\end{array}$ & $\begin{array}{c}136 \\
203 \\
252 \\
122.5 \\
116.5 \\
139.5 \\
65 \\
64.3 \\
112 \\
132 \\
152 \\
13.9 \\
16.1\end{array}$ & $\begin{array}{l}506 \\
570 \\
620 \\
447 \\
472 \\
496 \\
417 \\
372 \\
429 \\
457 \\
470 \\
307 \\
312\end{array}$ & $\begin{array}{l}370 \\
367 \\
368 \\
325 \\
356 \\
357 \\
352 \\
308 \\
317 \\
325 \\
318 \\
293 \\
296\end{array}$ & $\begin{array}{l}348 \\
317 \\
308 \\
338 \\
622 \\
500 \\
374 \\
184 \\
247 \\
278 \\
272 \\
186 \\
269\end{array}$ \\
\hline
\end{tabular}

creased excretion of glucose in patients with reduced kidney function depends only on the reduction of the filtration rate. The filtered quantity of glucose decreases so much that the reduction of the filtering surface causes a retention of sugar. The reabsorbed quantity decreases in the same proportion. The glucose threshold remains absolutely unchanged within the same limits as in the normal subject. The only explanation for this fact is that a reduction of the filtration at glomerular lesions is accompanied by a corresponding reduction of whole functional units of nephrons. In Case 1 the filtration decreased to a minimal amount, whereas the capacity of glucose reabsorption in the still functioning nephrons remained normal. Suppose that in a normal subject the quantity of reabsorbed glucose is 300 mgm. per minute, at a number of 2,000,000 nephrons: then one of them reabsorbs 0.15 microgram. In our case only $3.6 \mathrm{mgm}$. glucose could

TABLE IV

Reduced kidney function

\begin{tabular}{|c|c|c|c|c|c|c|c|c|c|c|}
\hline Technic & $\begin{array}{l}\text { Subject } \\
\text { and sex }\end{array}$ & Diagnosis & $\begin{array}{l}\text { Urine } \\
\text { flow }\end{array}$ & $\begin{array}{c}\text { Creati- } \\
\text { nine } \\
\mathbf{U} / \mathbf{P} \text { ratio }\end{array}$ & $\begin{array}{l}\text { Filtra- } \\
\text { tion } \\
\text { rate }\end{array}$ & $\begin{array}{c}\text { Sugar } \\
\text { in } \\
\text { urine }\end{array}$ & $\begin{array}{l}\text { Supra- } \\
\text { limitary } \\
\text { blood } \\
\text { glucose }\end{array}$ & $\begin{array}{l}\text { Blood } \\
\text { sugar }\end{array}$ & $\begin{array}{l}\text { Thresh- } \\
\text { old }\end{array}$ & $\begin{array}{l}\text { Reab- } \\
\text { sorbed } \\
\text { glucose }\end{array}$ \\
\hline $\begin{array}{l}\mathbf{B} \\
\mathbf{B}\end{array}$ & $\begin{array}{l}\text { Soy, m. } \\
\text { Emin, m. }\end{array}$ & $\begin{array}{l}\text { Amyloidosis } \\
\text { Chronic nephritis }\end{array}$ & $\begin{array}{c}\text { cc. per } \\
\text { minute } \\
0.84 \\
0.89 \\
1.0 \\
1.44 \\
1.81\end{array}$ & $\begin{array}{l}2.16 \\
2.06 \\
24.5 \\
17.95 \\
13.75\end{array}$ & $\begin{array}{c}c c . \text { per } \\
\text { minute } \\
1.82 \\
1.83 \\
24.5 \\
25.9 \\
24.9\end{array}$ & $\begin{array}{c}\text { mgm. per } \\
\text { cent } \\
580 \\
715 \\
270 \\
660 \\
870\end{array}$ & $\begin{array}{c}\text { mgm. per } \\
\text { cent } \\
269 \\
347 \\
11 \\
37 \\
63\end{array}$ & $\begin{array}{c}\text { mgm. per } \\
\text { cent } \\
471 \\
545 \\
272 \\
298 \\
336\end{array}$ & $\begin{array}{l}\text { mgm. per } \\
\text { cent } \\
202 \\
198 \\
261 \\
261 \\
273\end{array}$ & $\begin{array}{c}\text { mgm. per } \\
\text { minute } \\
3.6 \\
3.7 \\
64 \\
67.7 \\
68\end{array}$ \\
\hline
\end{tabular}


TABLE V

Interaction of blood sugar level, filtration rate and renal threshold during excretion of glucose under various conditions

\begin{tabular}{|c|c|c|c|c|}
\hline \multirow{2}{*}{ Condition } & \multicolumn{2}{|c|}{ Glucose filtered } & Glucose reabsorbed & \multirow{2}{*}{ Glucose excreted at } \\
\hline & Blood sugar level & Filtration rate & Renal threshold & \\
\hline 1. Normal & Normal & Normal & Normal & $\begin{array}{l}\text { Blood sugar values arti- } \\
\text { ficially increased above } \\
\text { the normal threshold }\end{array}$ \\
\hline 2. Phlorizin glycosuria & Normal & $\begin{array}{l}\text { Normal or slightly } \\
\text { reduced }\end{array}$ & Low or non-existent & $\begin{array}{l}\text { Normal or decreased } \\
\text { blood sugar values }\end{array}$ \\
\hline 3. Diabetes renalis & Normal & Normal & Low & $\begin{array}{l}\text { Normal or decreased } \\
\text { blood sugar values }\end{array}$ \\
\hline 4. Pregnancy glycosuria & Normal & Normal & Low & $\begin{array}{l}\text { Normal or decreased } \\
\text { blood sugar values }\end{array}$ \\
\hline 5. Diabetes mellitus & Increased & Normal & Normal & $\begin{array}{l}\text { Blood sugar values in- } \\
\text { creased above the nor- } \\
\text { mal threshold }\end{array}$ \\
\hline $\begin{array}{l}\text { 6. Diabetes mellitus in } \\
\text { advanced age }\end{array}$ & Increased & Normal & Increased & $\begin{array}{l}\text { Relatively high blood } \\
\text { sugar values }\end{array}$ \\
\hline $\begin{array}{l}\text { 7. Reduced renal func- } \\
\text { tion }\end{array}$ & Normal & $\begin{array}{l}\text { Reduced by destruc- } \\
\text { tion of functional } \\
\text { units }\end{array}$ & Normal & $\begin{array}{l}\text { Very high blood sugar } \\
\text { values after injection } \\
\text { of glucose }\end{array}$ \\
\hline $\begin{array}{l}\text { 8. Diabetes mellitus with } \\
\text { reduced renal func- } \\
\text { tion }\end{array}$ & Increased & $\begin{array}{l}\text { Reduced by destruc- } \\
\text { tion of functional } \\
\text { units }\end{array}$ & Normal or increased & $\begin{array}{l}\text { Very high blood sugar } \\
\text { values }\end{array}$ \\
\hline $\begin{array}{l}\text { 9. Functional disorgani- } \\
\text { zation of the kidney }\end{array}$ & Normal & $\begin{array}{l}\text { Reduced with pre- } \\
\text { served tubular } \\
\text { function }\end{array}$ & Extremely increased & $\begin{array}{l}\text { Extremely high blood su- } \\
\text { gar values after injec- } \\
\text { tion of glucose }\end{array}$ \\
\hline $\begin{array}{l}\text { 10. Diabetic coma with } \\
\text { functional disorgan- } \\
\text { ization of the kidney }\end{array}$ & Increased & $\begin{array}{l}\text { Reduced with pre- } \\
\text { served tubular } \\
\text { function }\end{array}$ & Extremely increased & $\begin{array}{l}\text { Extremely high blood } \\
\text { sugar values }\end{array}$ \\
\hline
\end{tabular}

be reabsorbed per minute. If we assume that in this case only 2 to 3 per cent of still functioning nephrons exist, that is 40,000 to 60,000 , the quantity reabsorbed from one nephron is nearly the same as in the normal one.

In cases with reduced kidney function caused by decrease of the number of functional units, glucose is retained like other constituents of the plasma. Only at very high blood sugar levels sufficient glucose is filtered to cause a frank glycosuria. We did not examine cases of diabetes with kidney disease, but it is beyond any doubt that the low glycosuria of these patients has to be explained in the same manner. In some patients who have suffered from diabetes for a long time, the glucose threshold is very high. If this condition is complicated by a kidney disease, a very high blood sugar will be necessary to produce a glycosuria.

\section{Functional disorganization of the kidney}

In certain conditions the filtration decreases temporarily by decrease of the blood pressure or by other extrarenal influences without any lesion of the single nephron itself. McCance and Widdowson (5) call this condition the "functional disorganization of the kidney." The filtration rate in the single glomerulus decreases, but the function of those parts of the tubules where glucose is reabsorbed remains unaltered. The filtered quantity of glucose decreases, while the reabsorbed quantity remains constant, and the excretion of glucose is greatly reduced or ceases completely. Shannon and Fisher (14) have demonstrated this process by an instructive experiment in Table III of their paper. In a decerebrated dog the reabsorption of glucose is examined before, during and after the application of a clamp 
to the upper abdominal aorta. During artificial decrease of the blood pressure to 50 to $66 \mathrm{~mm}$. $\mathrm{Hg}$, the maximal reabsorbed quantity of glucose remains constant, in spite of the reduction of the filtration rate and corresponding reduction of the filtered quantity of glucose by half. The glucose threshold, which before tightening the clamp lay between 360 and $370 \mathrm{mgm}$. per cent, suddenly rises to 620 to $650 \mathrm{mgm}$. per cent.

In the condition of functional disorganization of the kidney two factors retard the appearance of glucose in the urine. The first one is the retention of glucose caused by the decrease of the filtration; the second one is the unaltered reabsorbing function of the tubules, by which they are able to reabsorb glucose from the decreased filtrate with an extremely high threshold value. This condition may be called reabsorption hyperglycemia:

It has been known for a long time that often in diabetic coma, in spite of extremely high blood sugar values, only traces of sugar are found in the urine. Sometimes, in spite of the presence of all the other symptoms, the diagnosis may be doubtful for the doctor because of the faint or negative reaction of sugar in the urine. McCance and Widdowson (5) have demonstrated that in such cases glucose is reabsorbed at a normal rate from a reduced glomerular filtrate.

The interaction of the three factors on which depends the excretion rate of glucose under various conditions is summarized in Table V.

\section{SUMMARY}

The appearance of glucose in urine depends on three factors: the blood sugar level, the filtration rate, and the renal threshold of glucose.

The tubular reabsorption of glucose has been examined by simultaneous determination of the endogenous creatinine clearance or the inulin clearance, the glucose excretion and the blood sugar level in 4 normal subjects, in 4 cases of renal diabetes, in 12 cases of diabetes mellitus, and in 2 cases of kidney disease.
The results of these various conditions have been discussed.

The author wishes to acknowledge his indebtedness to Professor E. Frank for encouraging these investigations, and to Dr. L. Shepard, of the American Hospital, Istanbul, for critically reviewing the manuscript.

\section{BIBLIOGRAPHY}

1. Falta, W., Die Zuckerkrankheit, Wien, Urban, 1936.

2. Govaerts, P., and Muller, P., Considerations sur le mécanisme de l'excrétion rénale du glucose. Bull. l'Acad. Roy. Med. Belg., 1938, 3, 491.

3. Govaerts, P., and Muller, P., The mechanism of glucose excretion by the kidney in diabetic dogs. J. Clin. Invest., 1939, 18, 25.

4. Hoff, F., Untersuchungen über den Einfluss von Lactoflavin und Corticosteron auf den künstlichen renalen Diabetes. Klin. Wchnschr., 1938, 17, 1535.

5. McCance, R. A., and Widdowson, E. M., Functional disorganization of the kidney in disease. $\mathrm{J}$. Physiol., 1939, 95, 36.

6. Möller, E., McIntosh, J. F., and Van Slyke, D. D., Studies of area excretion; relationship between urine volume and the rate of urea excretion by normal adults. J. Clin. Invest., 1928, 6, 427.

7. Monasterio, G., Histologischer und physiopathologischer Beitrag zur Pathogenese des Diabetes renalis. Klin. Wchnschr. 1939, 18, 538.

8. Neuberg, C., Der Harn, Springer, Berlin, 1911.

9. Peters, J. P., and Van Slyke, D. D., Quantitative Clinical Chemistry. Williams and Wilkins, Baltimore, 1932.

10. Popper, H., Mandel, E., and Meyer, H., Zur Kreatininbestimmung im Blute. Biochem. Ztschr., 1937, 291, 354.

11. Roe, J. H., A colorimetric method for the determination of fructose in blood and urine. J. Biol. Chem., 1934, 107, 15.

12. Rühl, A., and Thaddea, S., Zur Frage des renalen Diabetes. Deutsches. Arch. f. klin. Med., 1938, $182,1$.

13. Sansum, W. D., and Woodyatt, R. T., Studies on the theory of diabetes. VIII. Timed intravenous injections of glucose at lower rates. J. Biol. Chem., 1917, 30, 155.

14. Shannon, J. A., and Fisher, S., The renal tubular reabsorption of glucose in the normal dog. Am. J. Physiol., 1938, 122, 765.

15. Steinitz, K., and Türkand, H., The determination of the glomerular filtration by the endogenous creatinine clearance. J. Clin. Invest., 1940, 19, 285.

16. Taylor, A. E., and Hulton, F., The limit of assimilation of glucose. J. Biol. Chem., 1916, 25, 173. 